\title{
Assessment of Potential Dam Sites in the Kabul River Basin Using GIS
}

\author{
RASOOLI Ahmadullah \\ Department of Information Engineering \\ University of the Ryukyus \\ Okinawa, Japan
}

\author{
KANG Dongshik \\ Department of Information Engineering \\ University of the Ryukyus \\ Okinawa, Japan
}

\begin{abstract}
The research focuses on Kabul River Basin (KRB) water resources infrastructure, management and development as there are many dams already in the basin and many dams are planned and are being studied with multi-purposes objectives such as power generation, irrigation and providing water to industry and domestics.
\end{abstract}

KB has been centralized all water resources related information in an integrated relational geo-database this $\mathrm{KB}$ is centralized repository for information river basin management with the main objectives of optimizing information collection, retrieval and organization. In addition, in this paper information and characteristics of the KRB has been presented such as drainage network or hydrology, irrigation, population, climate and surface pattern other necessary features of the basin by the use of GIS in order to invest and implement infrastructure projects.

The first step in doing any kind of hydrologic modeling involves delineating streams and watersheds, and getting some basic watershed properties such as area, slope, flow length, stream network density, etc. Traditionally this was (and still is) being done manually by using topographic/contour maps. With the availability of Digital Elevation Models (DEM) and GIS tools, watershed properties can be extracted by using automated procedures.

The processing of DEM to delineate watersheds is referred to as terrain pre-processing. Besides that, it produced the necessary thematic maps, base maps and other detailed maps for illustrating basin characteristics and features GIS Based.

Keywords-Geographical Information System (GIS); Kabul River Basin (KRB); Digital Elevation Model (DEM); Map

\section{INTRODUCTION}

Geographical information system (GIS) is an efficient tool for analyzing, collecting, storing, manipulating, displaying, editing vector and raster data for particular purposes. So using GIS can also play a crucial role in assessing potential sites for dam selection by hydrological analysis and modeling.

Kabul RB has $35 \%$ population density of the country and Fifty-nine percent population of the basin is rural and lives outside Kabul; more than 96 percent live in small villages and settlements, primarily along the rivers in cultivable areas with Access to water. Rain-fed agriculture is only approximately 3 percent of the total cultivated area in the basin.
Agriculture constitutes is the major income source for the population in the Kabul Basin study area and the economic development is in many respects connected to the presence of water resources and their rational use.

Over the last 40 years, there have been very intensive human-induced environmental changes in this area, primarily associated with irrigation activities, changes in the grazing pressure on desert rangelands and deforestation.

In addition many dams have at least some flood mitigation effects to their primary purposes. However for the assessment of potential dam sites in the KRB created Knowledge Base (KB) and Geo-database also produced thematic maps, base maps and required detail maps for the basin water resources infrastructure development projects as well as water resources management in the basin.

Dams are one of the prime options to store and use the water more efficiently and improve living condition for rural and urban population by providing electricity, water for industry, irrigation and drinking [1].

In this paper $\mathrm{KB}$ has been centralized all water resources related information in an integrated relational geo-database this $\mathrm{KB}$ is centralized repository for information river basin management with the main objectives of optimizing information collection, retrieval and organization. So besides information and characteristics, KRB has also been explained such as drainage network/system or hydrological features, irrigation, population, climate and so on illustrated as maps and graphs.

The presented methodology and required data sources can be the basis for an actual pilot study on a limited area to test and to calibrate. Thus for Hydrological analysis and modeling Areal-photos, Satellite image and DEM 90m SRTM also vector data has been processed, digitized and also extracted and computerized all required surface features data and information stored as database.

\section{STUdy SITE}

\section{A. The principle sub-basins of Kabul River Basin}

Kabul RB is a 700 kilometer long river that starts in the Sanglakh Range of the Hindu Kush Mountains in Afghanistan and ends in the Indus River near Attock, Pakistan [2]. This RB has been located in south-east of Afghanistan and it is the portion of the Indus River catchments. the total catchment area of Kabul RB is about 76,908 (Sq km) including 14,000 (sq km) 
of the upstreams sub catchments which is located in Pakistan. And many big provinces and cities are situated in the basin such as Wardak, Kabul, and Jalalabad so on, and also major tributaries are considered in the Basin like Kunar, Logar, Kabul and Panjsher.

The eastern part of the basin which is originated from Pakistan has higher elevations, and covered by snow most of the year. About $72 \%$ of total runoff is originated from this part of the basin. Because of the elevation variation (400-6,000 m) As shown in Fig. 1, This part of basin has considerable potential to install hydropower.

Western part of the basin is relatively dry shortage for water especially in dry season [3].

From the standpoint of climate, hydrology, and physiographic characteristics, the Kabul River basin is divided into three distinct sub basins as shown in Fig. 1.

The upper basin consists of two major sub basins the Panjshir sub basin and the Logar-Upper Kabul sub basin and. The third sub basin is the Lower Kabul, which encompasses the watershed area from the confluence of the Panjshir and Upper Kabul rivers near the head of the Naglu reservoir to the border with Pakistan and Shmal Khuram watershed includes mostly Paktia and Khost provinces.

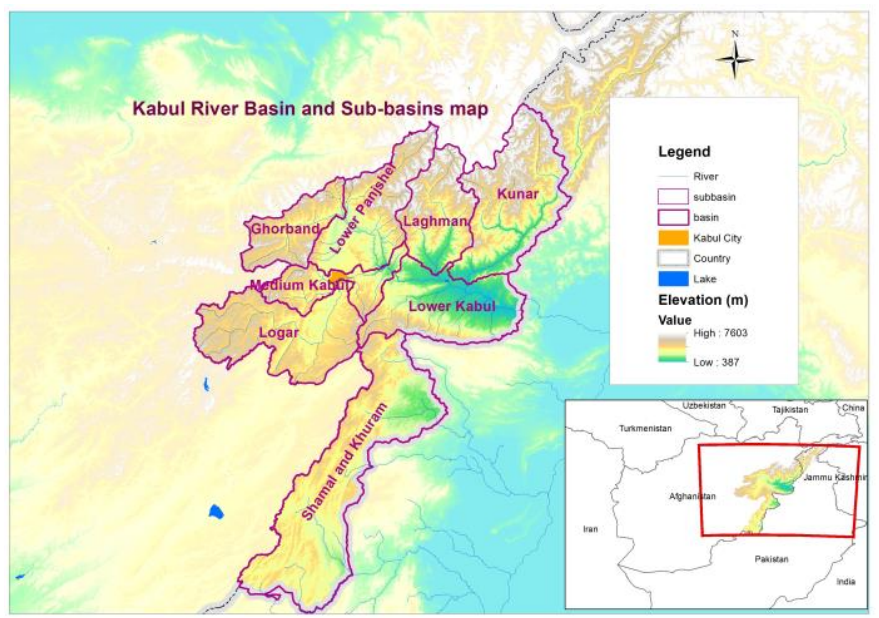

Fig. 1. Shows Kabul River Basin's and Sub-basins

\section{B. The basin designed Maps}

These maps have been produced in three sections with various scale such as $(1: 2000,000,1: 500,000$ and 1:750,000 etc).

a) Base Maps such as (river and sub-basins base map, river infrastructure and irrigation, hydro-meteorological stations, administrative units, basin administrative and management, population and population concentration, topography/elevation, regional setting (Indus Basin)).

b) Thematic Maps have also been made for the basin namely precipitation and temperature regime, hydrographs, snow coverage, energy infrastructure, soil taxonomy, land use and land cover, terrestrial ecoregions, geology, geological faults respectively. c) The more detailed sub-basins Maps consisted of subbasins lower Kabul and Kunar, sub-basins Middle Kabul and Panjsher and sub-basins Logar/ Shamal and Khuram respectively.

Therefore each section has consisted of different maps with multi-purposes created by using GIS and Arc-hydro tools and it's applications for water resources development and infrastructure projects.

\section{KNOWLEDGE BASE AND GEO-DATABASE}

Geo-database and Knowledge Base in Arc GIS are organized and contain of the required data (raster and vector) As national level for Kabul basin. Fig. 2, shows the hierarchical data structure of the geo-database formed of

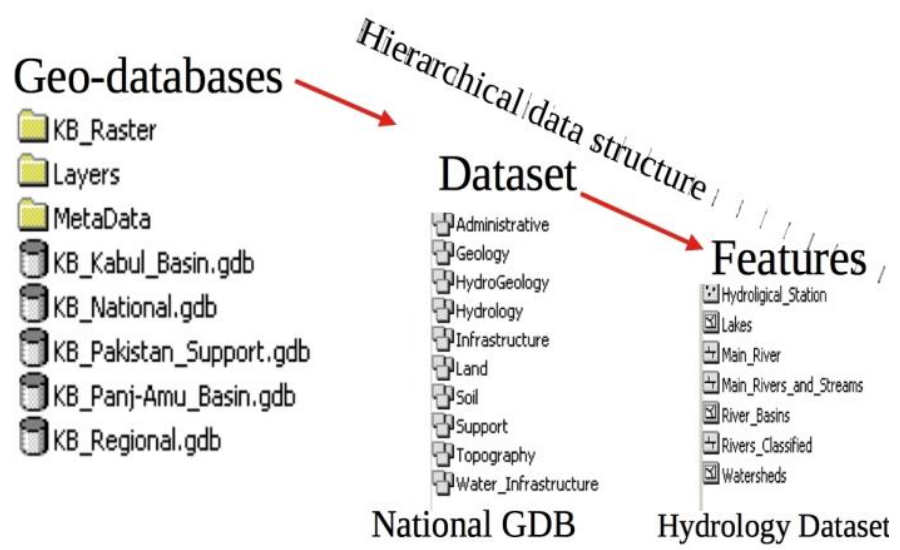

datasets and feature classes.

Fig. 2. Shown the structure of geo-database in Arc GIS

\section{DATA USED}

By using Arc GIS tools based on required data for the basin, Arc-hydro and it is applications hydrological analysis, mapping (thematic, base) and modeling, raster data such as (Areal-photos, Satellite images and Digital Elevation Model (DEM) (90m SRTM) Landsat imagery) and also vector as well as statistic and historical series data from Central Statistics Office (CSO) has been used and processed, also including information on the hydrological network, irrigation, energy infrastructure and general themes such as climate, soils, geology, land use and ecosystems etc.

The raw data and information related to the study area Kabul basin were obtained from various sources like Afghanistan Information Management Services (AIMS), United States Geological Survey (USGS), Ministry of Energy and Water (MEW), company Consultative Group on International Agricultural Research (CGIAR), World Wide Fund (WWF), Food and Agricultural Organization (FAO) etc. All the data is stored as geo-database was shown above the structure hierarchically.

\section{METHODOLOGY}

It is a perfect way of considering the information and data on Kabul basin water resources development and assessing potential dams sites in the basin and focusing on the following issues. 
a) Literature reviewed on the current environment in the Kabul Basin on the main parameters influencing dam site location methodologies for dam site assessment with a focus on GIS techniques.

b) Thorough understanding of the existing methodology in order to define the processes involved and to assess the feasibility of such activity in the country (data availability, GIS techniques required).

These included:

- GIS methodology for initial site screening using terrain data followed by more detailed assessment of the sites obtained from the generic terrain screening

- GIS also used for water resources assessment of the future available water in the dam's catchment area

- Procedures that took into account thematic maps, base maps and other detailed maps has been generated for the basin and definition of characteristics of dam site location assessment.

- Asses availability of required geological data layers assist with assessing suitability of the underground for dam implantation.

- Geo-database and knowledge base management and development.

\section{c) FUNCTIONALITY OF AR CHYDRO}

The Arc Hydro Toolset is a suite of tools which facilitate the creation, manipulation, and display of Arc Hydro features and objects within the ArcMap environment. The tools provide raster, vector, and time series functionality, and many of them populate the attributes of Arc Hydro features [4].

\section{1) Terrain preprocessing}

Terrain Preprocessing uses DEM to identify the surface drainage pattern. Once preprocessed, the DEM and its derivatives can be used for efficient watershed delineation and stream network generation.

- Level DEM: assign constant elevations under lake polygons

- DEM Reconditioning: burn in existing streams

- Build Walls: burn in existing boundaries

- Fill Sinks: This function fills the sinks in a grid. If a cell is surrounded by higher

Elevation cells, the water is trapped in that cell and cannot flow. The Fill Sinks function modifies the elevation value to eliminate these problems.

2) Terrain Processing

Terrain Processing - the functions that will create the data supporting the delineation process:

- Adjust Flow Direction in Lakes

- Flow Accumulation - computes the flow accumulation grid that contains the accumulated number of cells upstream of a cell, for each cell in the input grid
- Stream Definition: This function computes a stream grid based on a flow accumulation grid and a user specified threshold.

- Stream Segmentation: This function creates a grid of stream segments that have a unique identification

- Catchment Grid Delineation: This function creates a grid in which each cell carries a value (grid code) indicating to which catchment the cell belongs.

- Catchment Polygon Processing

- Drainage Line Processing

- Adjoint Catchment: This function generates the aggregated upstream catchments from the "Catchment" feature class

- Drainage Point Processing: This function allows generating the drainage points associated to the catchments

- Longest Flow Path for Catchments

3) DEM Pre-processing

There are four key elements that define the expected "behavior" of the flow patterns in the terrain:

a) Sinks (depressions, pits). Sinks are the areas into which the water flows but does not exit as surface flow. In DEMs, most of the sinks are artificial and are artifacts of DEM construction. There are also real sinks. Sinks can be a function of the analysis. For low flow conditions, some sinks will capture water that will never leave the sink and will not contribute downstream, while under high flows, they will fill and spill over the sink boundary and eventually contribute to the flow downstream.

b) Known streams: Known streams represent observed drainage patterns captured as a vector polyline layer. The expectation is that the drainage pattern generated by the DEM will match the drainage pattern represented by the vector layer.

c) Known lakes. Known lakes represent observed lakes captured as a vector polygon layer. Lakes can be either sinks, where all the water drains into the lake and none comes out, or they can have an outlet stream (in which case the water entering the lake will exit through the stream draining the lake).

d) Known drainage area boundaries. Known drainage area boundaries represent known boundaries captured as vector polygon layers. Any "droplet" of water will stay within the drainage boundaries and drain either to the sink within the drainage area or to one drainage area outlet point [5]. DEM Pre-processing with hydrological is a part conducted in Arc hydro tool as the data supporting process:

- DEM Reconditioning- This function modifies a DEM by imposing linear features onto it (burning/fencing). The function needs as input a raw dem and a linear feature class (like the river network) that both have to be present in the map document. 
- Fill sinks- This function fills the sinks in a grid. If a cell is surrounded by higher elevation cells, the water is trapped in that cell and can not flow. The Fill Sinks function modifies the elevation value to eliminate these problems, The output is the Hydro DEM layer, named by default Fil.

- Flow Direction- This function computes the flow direction for a given grid. The values in the cells of the flow direction grid indicate the direction of the steepest descent from that cell.

- Flow Accumulation- Computes the flow accumulation grid that contains the accumulated number of cells upstream of a cell, for each cell in the input grid.

- Stream Definition- This function computes a stream grid based on a flow accumulation grid and a user specified threshold. The cells in the input flow accumulation grid that have a value greater than the threshold are assigned a value of 1 in the stream grid. All other cells are assigned no data.

- Stream Segmentation- This function creates a grid of stream segments that have a unique identification. Either a segment may be a head segment, or it may be defined as a segment between two segment junctions. All the cells in a particular segment have the same grid code that is specific to that segment.

- Catchment Grid Delineation- This function creates a grid in which each cell carries a value (grid code) indicating to which catchment the cell belongs. The catchments correspond to your river segments - the more segments you have, the more catchments will be generated. The value corresponds to the value carried by the stream segment that drains that area, defined in the stream segment link.

- Catchment Polygon processing- Converts the raster data developed so far to vector format. The rasters created until now have all been stored in a folder named Layers. The vector data will be stored in a feature dataset also named Layers within the geodatabase associated with the map document.

- Drainage line processing- This function converts the input Stream Link grid into a Drainage Line feature class. Each line in the feature class carries the identifier of the catchment in which it resides.

- Drainage point processing- This optional function allows generating drainage points associated with individual catchment.

\section{4) Watershed processing}

Arc Hydro toolbar also provides an extensive set of tools for delineating watersheds and sub- watersheds. These tools rely on the datasets derived during terrain processing this has been done for delineating sub watersheds for existing points (eg. gaging sites) and batch watershed delineation.

\section{SIMULATION EXPERIMENT}

\section{A. kabul river basin regional setting (indus basin)}

Briefly in terms of regional setting illustrates the extent and location of the KRB within the Indus Basin, that covers Afghanistan, India and China as well as a larger part of Pakistan. The basin has a total drainage area exceeding $1,165,000 \mathrm{~km} 2$ and it has been estimated annual flow stands at around $207 \mathrm{~km} 3$.

The Indus Basin comprises of the Indus River, its five major left bank tributaries the Jhelum, Ravi, Chenab, Sutlej, and Beas rivers and one of major right tributary the Kabul River Fig. 3.

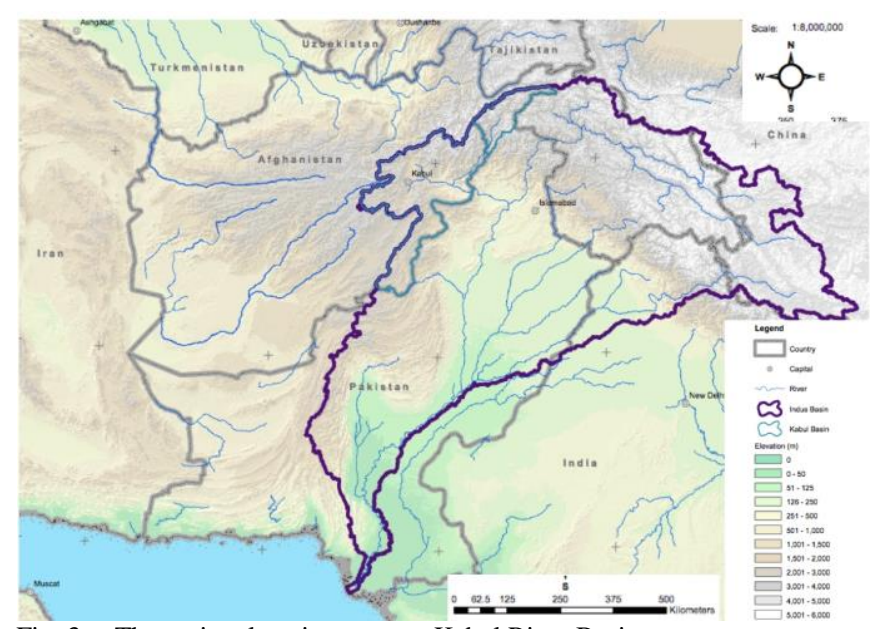

Fig. 3. The regional setting map on Kabul River Basin

\section{B. Topography And Elevations}

The elevation presented in this map is from SRTM version4 DEM dataset in combination with shaded relief overlap for presentation enhancement Fig. 4. The river system/ network has been computed form the same DEM through hydrological modeling.

The elevation map highlights the relief of the Kabul Basin and illustrates the shape of the land surface its topography. The elevation, in combination with land cover, surface roughness, and soil characteristics is the most necessary factor defining the hydrological characteristics of the river basin and its drainage system. 


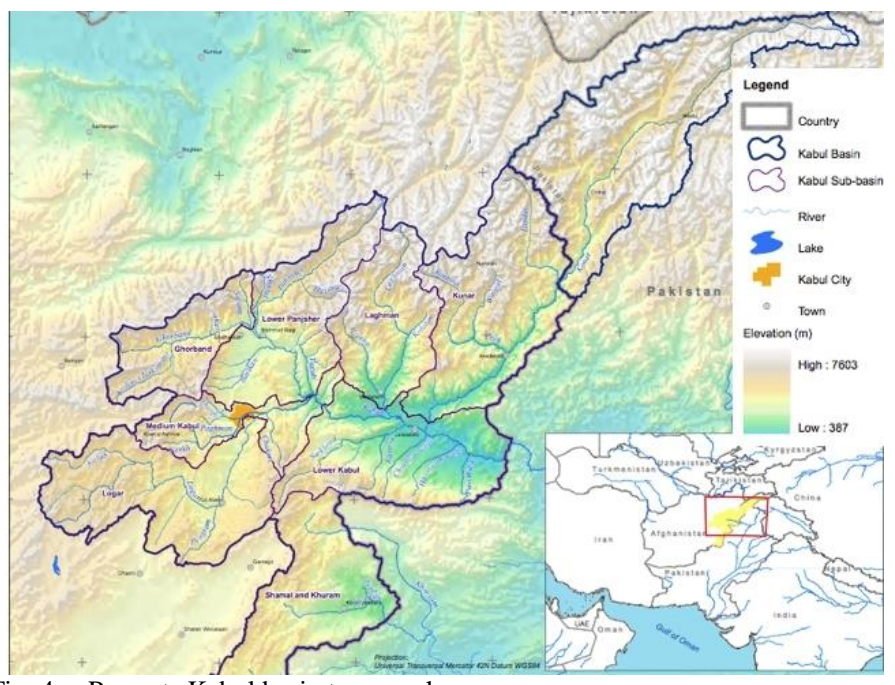

Fig. 4. Presents Kabul basin topography

\section{River classification and codification}

Kabul River left bank and right bank tributaries classified and codified in attribute the river coding creates a unique codification support for river and hydrological stations and allows linking the GIS layers with other data in the KB. A river code number consists of three groups:

- The first group relates to the main river basin in which the river lies.

- The second group stands for first order tributary.

- The third group generally consists of three digits and stands for various "second order" and "third order" tributaries listed in serial order, and a latter " $L$ " or " $R$ " for left bank tributary and right bank tributary respectively.

The Fig. 5, provides a schematic diagram of the Kabul river and its main tributaries - including naming and coding system.

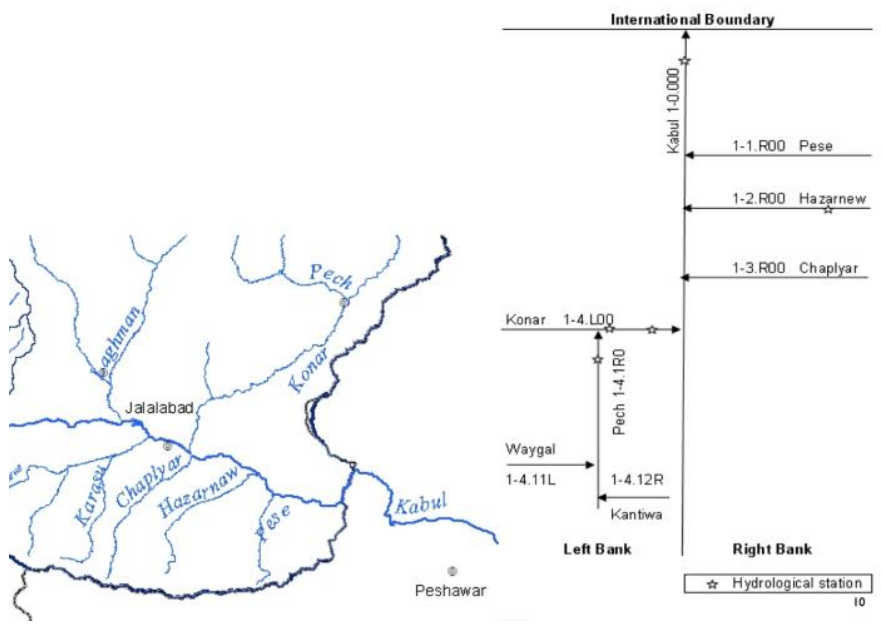

Fig. 5. Shows rivers classification and codification

\section{Kabul administrative units}

The river and sub-basins map present the river system and watersheds in the Kabul Basin. Basin and sub-basins are natural stream drainage areas used for collecting and organizing hydrologic data.

GIS layers have been consisted of their feature and attributes, this map presenting Kabul Basin administrative units, the administrative divisions of Afghanistan is districts and provinces respectively. There are 34 provinces in the country, and province is further divided into districts in total there are 127 districts in the Kabul basin Fig.6, This basin has been covering ten provinces such as Kabul, Wardak, Logar, Nangrahar, Kunar, Nuristan, Laghman, Kapisa, Panjsher, Parwan as well as some part of Ghezni province. Except for the Ghazni province and Wardak, the basin boundaries correspond to the provincial boundaries.

Other four basins of the country (Panj Amu, Northern river basin, Harirud Murghab river basin, Helmand river basin) cover the remaining provinces and districts.

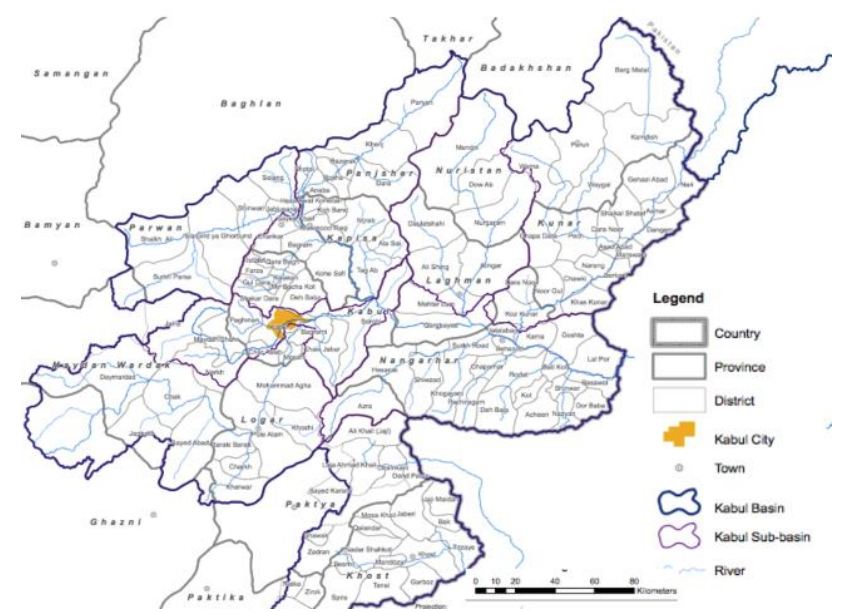

Fig. 6. Illustrates Kabul basin administrative divisions

\section{E. river infrastructure and irrigation}

Using GIS application plays a significant role in river basin management and dams site selection as well as water infrastructure projects ( existing, planed and being studied) in the basin based on raster and vector required data.

The irrigated areas have been estimated from satellite image interpretaion and classification using Landsat imageries presents the current situation of Kabul River Basin Afghanistan.

The most important water uses in the KRB included irrigation, energy generation, and industrial as well as uses for domestics. In Fig. 7, map illustrates the location of water infrastructure existing and planned projects and also dams site locations as well as the main urban centers and irrigated areas in the basin. In addition, representations of these layers can also be found in the more detailed sub-basins maps. 


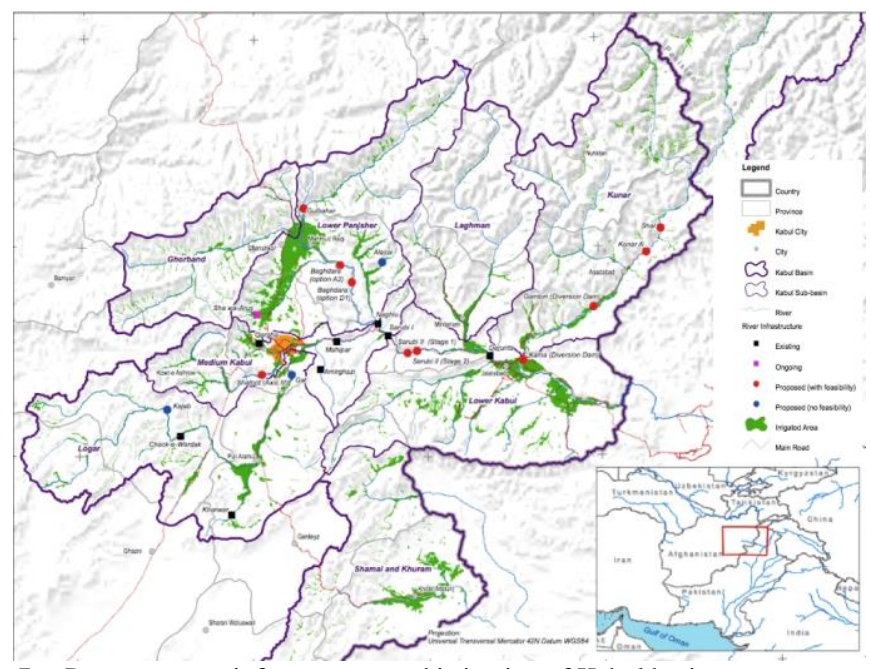

Fig. 7. Presents water infrastructure and irrigation of Kabul basin

\section{THEMATIC MAPS}

As mentioned before in terms of the name of some thematic maps that have been produced for realizing the basin characteristics and features. Thematic map emphasizes a particular theme or special topic such as the average distribution of rainfall in an area as we as meteorology or hydro-meteorological of an area.

They are different from general reference maps because they do not just show natural features like rivers, cities, political subdivisions and streets. Instead, if these items are on a thematic map, they are simply used as reference points to enhance one's understanding of the map's theme and purpose.

\section{A. population density}

This dataset has a $1 \mathrm{~km}$ resolution (30" X 30"), and is the finest resolution global population distribution data. The algorithm uses spatial data and imagery analysis technologies and a multi-variable asymmetric modeling approach to disaggregate census counts within an administrative boundary [7].

GIS has used for the analyzing population density based on the required GIS data for the basin, statistic data has been gotten from the Central Statistic Office (CSO), while the raster dataset shown is from the Landscan dataset.

The population map in Fig. 8, presents the total population by district in the Kabul. The latter dataset illustrates the areas with higher population density, and confirms the strong correlation of population density with irrigated areas along the river systems.

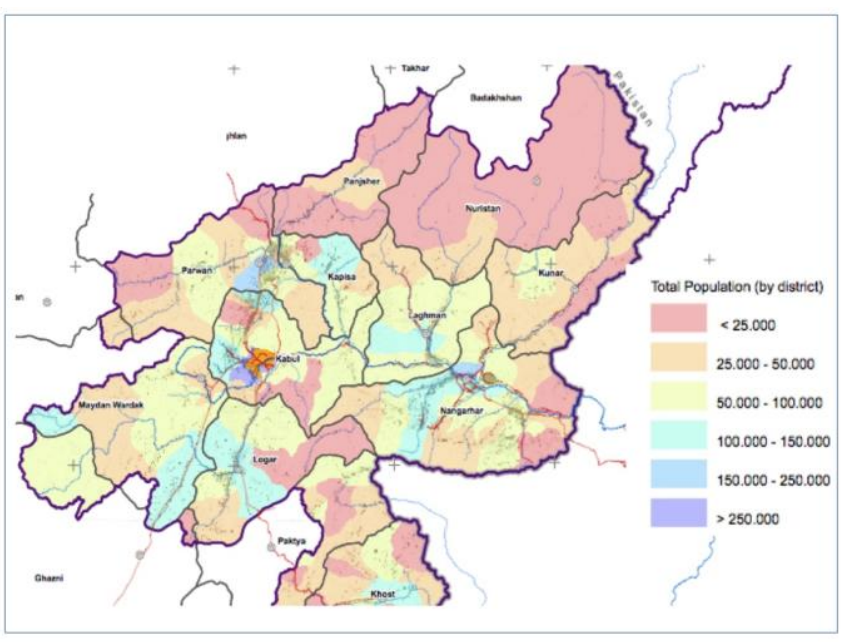

Fig. 8. Shows total Population density by district in Kabul basin

\section{B. Hydro-meteorology of the basin}

The hydrographs show the flow rate (discharge) versus time past a specific point in a river. The rate of flow is typically expressed in cubic meters per second.

River flow data is one of the main input data for effective river basin management. In surface water hydrology, a Hydrograph is a time record of the discharge of a stream, river or watershed outlet. Rainfall and/or snowmelt is typically the main driver of watershed discharge and a hydrograph records how a watershed responds to these and other drivers of watershed hydrology [8]. For instance Fig. 9, presents the graph of hydrological station of Tangi Saidan on Kabul River let to present this station point as it's been take into consideration and generated from the historical available data using GIS tool.

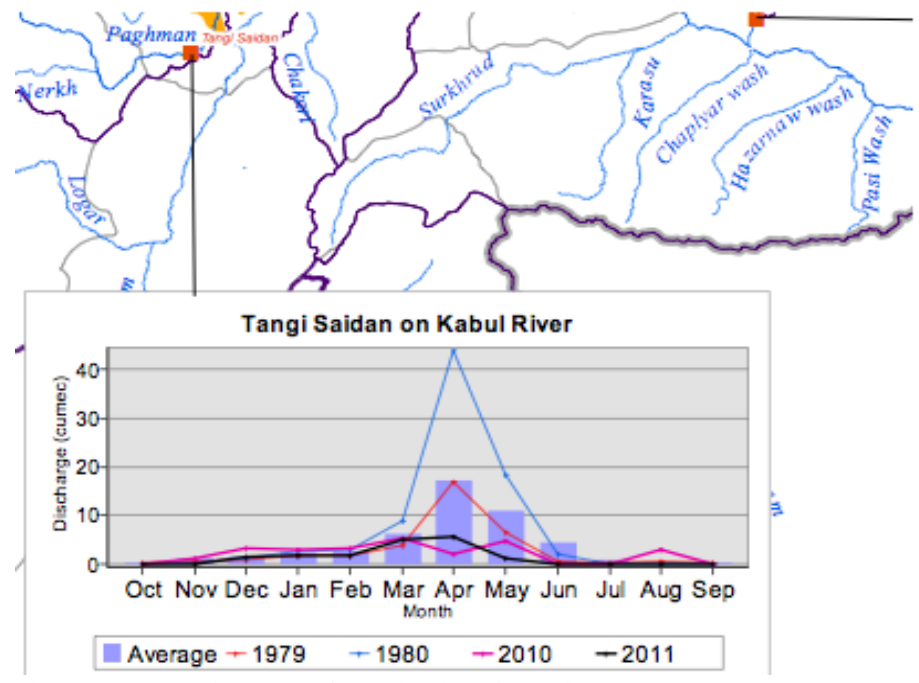

Fig. 9. Shown discharge of Tangi Saidan in cubic meter 


\section{Precipitation and temperature}

This map in Fig. 10, presents the average yearly precipitation (rainfall and snow) over the Kabul Basin. Precipitation variability is extreme in the basin and in strongly correlated with the elevation. Precipitation ranges from $200 \mathrm{~mm}$ or less around Jalalabad (semi-arid climate) up to $3000 \mathrm{~mm}$ or more in the high altitudes in the northern part of the basin (highland climate) [9].

The graphs near the show the monthly precipitation and temperatures in a few selected locations, where a climate station is located.

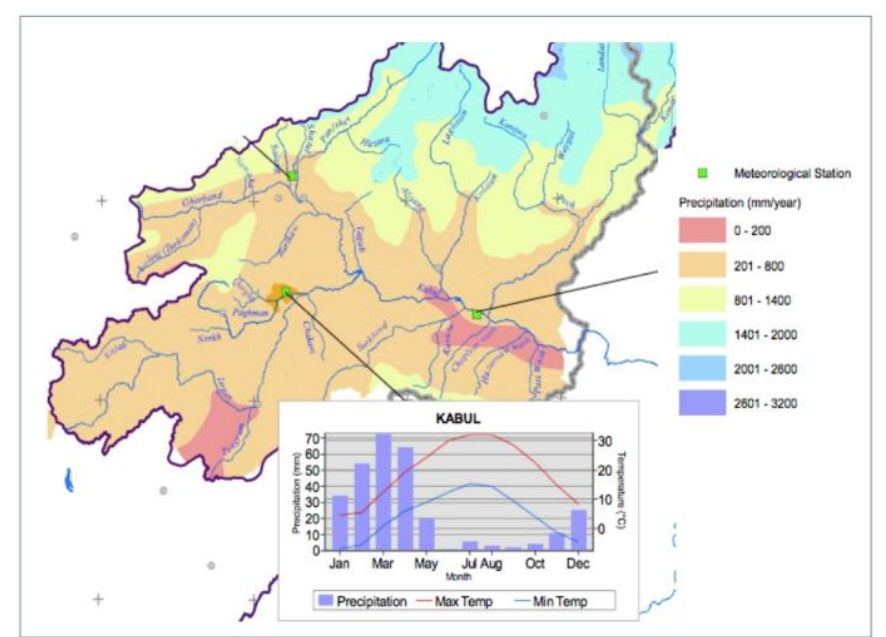

Fig. 10. Shown precipitation and temperature of Kabul basin

This data is very important for water resource infrastructure development and also for knowledge and knowing about the features of the basin for implementation of projects not only for water resources but also for other projects such as irrigation and water supplement projects as well as for investment plan in the basin critically needed either large and medium water infrastructure projects. The population has been increasing rapidly in the basin and water demand and economic growth demand increase.

\section{ACKNOWLEDGMENT}

I am grateful for Japan International Cooperation Agency (JICA) Project For the Promotion and Enhancement of the Afghan Capacity for Effective Development (PEACE) and University of the Ryukyus for the given opportunity and their financial support, so the product of this International Journal paper would not be possible without them.

\section{REFERENCES}

[1] Akbari, M.A, Tahir, M,Litke, D.W and Chornack, M.P, "Ground-water levels in the Kabul basin, Afghanistan", U.S Geological Survey Openfile report, pp. 46, March 2007.

[2] Thomas J. Michael P. Chonack, Mohammad R. Taher "Ground WaterLevel trends and implications for sustainable water use in the Kabul Basin, Afghanistan," Afghanistan Geological Survey, pp.457-467, September 2013.

[3] Ali Ershadi, Hamid Khiabani, Jens Kristain Lorup "applications of Remote Sensing, GIS and River Basin Modelling in integrated Water Resource Management of Kabul River Basin", TOOSS AB consulting Engineering, Mashhad, Iran. pp. 10, May 2005.

[4] Rasooli Ahmadullah, Kang Dongshik,"Assessment of potential dam site in the Kabul basin using Geographical Information System," University of The Ryukyus, Japan, International Technical Conference on Circuits/Systems, Computers and Communications (ITC-CSCC) Phuket, Thailand, pp. 521-524, July 2014.

[5] Sabbar Abdulla Salih, Abdul Salam Mehdi Al-Tarif, "Using of GIS Spatial Analyses to Study the Selected Location for dam reservoir on Wadi Al-Jirnaf, west of Shirqat area, Iraq" University of Tikrit, Iraq, pp. 117-127, January 2012.

[6] Mudher N. Abdulla, Senior Chief Engineer, MSc in photogrammetry \& RS, Expert in GIS \&RS, MOWR - IRAQ, "Catchment Area Delineation Using GIS technique for Bekhma Dam”, pp.18.May 2011.

[7] Anwar M.M. ${ }^{1}$, Bhalli M.N. ${ }^{2}$ "Gojra, Pakistan. urban population growth monitoring and land use classification by using GIS and remote sensing techniques acase study of faisalabad city", Department of Geography, GC University Faisalabad, \& ${ }^{2}$ Department of Geography, Govt. Postgraduate College, February 2012.

[8] Sustainable Development Department South Asia Region WB, "Scoping Strategic Options for Development of the Kabul River Basin". A Multisectoral Decision Support System Approach 2010 Afghanistan, 1818 H Street, NW, Washington, D.C. 20433 USA.

[9] Aquastat, Afghanistan, Food and Agriculture Organization (FAO) of the United Nation, "Geography, climate and population Geography", 2012. 